Agnieszka Sowa-Kofta

Institute of Labour and Social Studies, Warsaw, Poland

\title{
RESPONDING TO THE COVID-19 IN RESIDENTIAL LONG- TERM CARE IN POLAND: WHAT HAS BEEN DONE TO INCREASE SAFETY OF THE ELDERLY
}

\section{Introduction}

Polish society is based on traditional, family-oriented values and despite the presence of various long-term care settings, the sector of publicly paid and provided care to the older, disabled and dependent persons in not well developed compared to Western European countries. Szatur-Jaworska (2018) points, the longterm care is hardly recognized within public debate as a system, constituting rather a set of policies and programmes within social and healthcare sector oriented at support of older, dependent or disabled people and their carers. In the late $70 \mathrm{~s}$ and $80 \mathrm{~s}$ of the $20^{\text {th }}$ century public debate regarding needs of the older population concentrated on income support and access to retirement pension, perceptions of the role of the elderly in the society and assurance of access to residential care (Szatur-Jaworska 2016).

When discussion on the population ageing were launched in the late 1990s, the concentration of policy makers was on rearrangement of the pension system (from pay-as-you-go to defined contribution system) (Golinowska, Sowa-Kofta 2017). Only in the second decade of 2000s more attention was given to other than income-related forms of support for older people. When a policy towards older people was launched in 2013 - following the European Commission year 2012 as a European Year of Ageing and Solidarity and Between Generations - it was a stimulus to undertake multiple activities towards the elderly, particularly oriented at increasing the engagement of local communities in creating conditions for activation of older people. The latter was supported with the governmental programme of grants for non-governmental organization, so called Programme of Social Activity for Older People (Program Aktywności Społecznej Osób Starszych - ASOS). In 2018 a new governmental policy was adopted entitled "Social Policy Towards Older People", with more focus on social needs of elderly, including care in different forms (Szatur-Jaworska 2018).

Care-oriented services and benefits for older people have been introduced well in advance of the policy itself, anchored in regulation on basic healthcare system provisions and social assistance. Various long-term care services and benefits are 
granted within the publicly funded healthcare system, social assistance and social security. In principle, cash benefits - so called nursing supplement - are granted from the social security universally, for all citizens covered with social insurance who reach the age of 75 or more. Additionally, those who are not covered by the social security can be granted a nursing benefit with family benefits system, financed from the central taxes.

Home care services can be granted by local self-governments and social assistance office. Still, about one third of the local governments does not provide this type of services as it is not obligatory and depends on the local authorities' ability to provide them. Similarly, local authorities can provide specialized care services, including services for people with psychiatric disorders. Home nursing services are provided based on the decision of a primary care physician by a community nurse. Nursing services are managed by primary care units and finances from the health insurance.

Residential care services are also granted within health and social assistance systems. Nursing and care institutional services are available for people in most severe health conditions (assessed as 40 points or below on the Barthel scale) and funded from the health insurance. Residential care in social welfare homes is available for people for whom family is unable to provide care and who need assistance in their activities. Despite a variety of types of services, their use is low. Estimates show that less than 1.1\% of older people receive care in public residential facilities either in the health or social sector.

The outbreak of Covid-19 put a pressure on long-term care from the first weeks of the pandemic. As in most of European countries, United States and Canada particularly residential care facilities were in danger of an outbreak and its negative consequences, including deaths of cared for. The pandemic immediately and painfully depicted weaknesses of the long-term care system. The article presents information on the Covid-19 epidemic in Poland and discusses methods adopted to respond to the outbreak in residential long-term care in the first months of the pandemic.

\section{Covid-19 outbreak in Poland}

The first case of Covid-19 was diagnosed in Poland in the first week of March 2020, several weeks after the outbreak in Western and Southern Europe. First cases were not related to long-term care but diagnosed among tourists coming back from Germany and Italy, but already midMarch cases in hospitals and long-term residential facilities were reported as well. The government decided to lockdown the economy and restrict mobility, as well as promote physical and social distancing as an immediate response to the outbreak, thus the number of cases was growing moderately reaching 2.2 thousand by the end of March. It should be noted however that the number of cases has been steadily growing since then, with the highest slope in October, reaching over 149 thousand 
cases/3308 deaths altogether and daily increase of 8.1 thousand cases on October $15^{\text {th }}$.

Older people constitute a large share of depicted cases and were mostly severely affected by negative consequences of the disease, including death. The data available at the end of May, following two months of the pandemics, showed that people aged 65 years or more constituted about $80 \%$ of all Covid-19 deaths and people aged 80 years or more about $44 \%{ }^{1}$.

\section{How long-term care was affected?}

Monitoring the number of infections in long-term care is difficult as officially published data does not point to infections by their source and the system of reporting has changed several times over the months following the outbreak. Also procedures related to access to SARS-Co-2 tests have been changing over time which has an impact on the number of diagnosed cases.

First cases of Covid-19 in long-term care institutions were diagnosed midMarch and were extensively covered by the media due to the problems that immediately occurred. Residential care was highly unprepared for the pandemic. Most frequently reported problems included poor access to SARS-Co-V-2 tests at the LTC facilities and problems with assurance of isolation of patients, particularly lying persons, at the facilities. Reasons of infections varied, but were similar to

Following information published on Twitter by the Ministry of Health. reported in other countries and included insufficient or even lack of protective equipment (masks, shields, gloves), insufficient preventive procedures, as well as multiple employment of nurses who often work at hospitals and care homes. Other problems were also reported, particularly with poor access to healthcare in social welfare homes. Studies show that transmission of COVID-19 is caused not only by symptomatic personnel or patients, but also asymptomatic family members or staff which fastens the paths of infection transmission (Comas-Herrera et al. 2020). At the same time older and disabled population are at the highest risk of negative consequences of infections, including death, due to multiple health problems. Symptoms of infection in older population may vary, including not only fever, caught and dyspnoea, but also diarrhoea, problems with memory and delirium, loss of appetite and falls most of them are typical for population living residents and nursing homes, thus the illness is even more difficult to distinguish from other diseases.

According to the governmental data of early June 2020 about $9 \%$ of COVID-19 cases were related to infections in long-term care facilitates in Poland: $3 \%$ in nursing and care homes and $6 \%$ in social welfare homes (Rządowe Centrum Bezpieczeństwa 2020). Still, the data on the sources of infections are not very accurate pointing to a large share of other (unknown) sources (41\%) and with the increasing number of cases sources become more difficult to trace. In the summertime 
the importance of long-term care units as sources of infections was decreasing as other sources became prominent: clubs and parties, weddings and infections in factories. In September school were reopened and the economy was back in full, both contributing to growing number of COVID-19 cases. By mid-October COVID-19 was reported in 113 social welfare homes ${ }^{2}$, out of about 800 . The number of care and nursing homes with reported COVID-19 cases is not covered by publicly available data. However, the number of private care facilities with infected patients is not monitored, so there is no full picture of infections in residential long-term care.

First cases of COVID-19 in social welfare homes and nursing and care homes were monitored by media with multiple problems reported. As long-term care is understaffed, shortages in the number of nurses and carers quickly became evident in facilities struggling with infections. In some facilities staff had to work even if experiencing COVID-19 symptoms as there was no replacement and there were several cases reported where only few of the care staff stayed on positions per facility, working day and night. Administrative bodies tried to mobilize personnel - nursing and carers - from other facilities, but struggled with difficulties. Problems with isolating infected persons and moving ill residents to hospitals were observed. Older people were reported to be confused and often not wanting to leave

http://www.dps.pl/koronawirus/ facilities. In cases of residents' evacuation army intervened to move patients to hospitals. In many locations local community was supporting carers in residential homes by bringing food, beverages and protective equipment (masks, gloves), often home-made. With time the situation has improved, particularly with access to protective equipment and procedures, though some of the problems with moving patients to hospitals or staff shortages are still reported, particularly as the number of infection is steeply growing and the number of beds available in hospitals for treatment of COVID-19 patients decreases, due to high occupation rate.

\section{Response to the crisis in residential care}

Not only the facilities themselves, but also public administration was caught by surprise by the pandemic and its impact on long-term care, which became one of the most vividly discussed issues in relation to the pandemic in mid-March. The decentralization of authority, with local authorities responsible for social welfare homes, and the split between healthcare and social sector had a negative impact on responding to the thread quickly and comprehensively. In case of social welfare homes, the management of the crisis depended on the ability of the local authorities and managers to mobilize the resources. Non-governmental organizations of the disabled people also became involved, lobbying for reaction of central authorities - the Ministry of Health and 
the Ministry of Family, Labour and Social Policy.

Eventually, the reaction came from several bodies: local authorities organized supply for residential care facilities with reported COVID-19 cases, improved management in order to introduce prevention measures; the central government decided to put additional financial resources for equipping facilities and increasing the remuneration of medical and nursing staff at the facilities and consultancy bodies in cooperation with public administration provided framework for introducing preventive procedures. The latter were prepared and published under the supervision of the Ministry of Health and the Ministry of Family, Labour and Social Policy by the national consultant in infectious diseases and national consultants in nursing, long-term care nursing and geriatric nursing. Recommendations, published early

Table 1. Recommendations issued by the national consultant in infectious diseases ${ }^{1}$

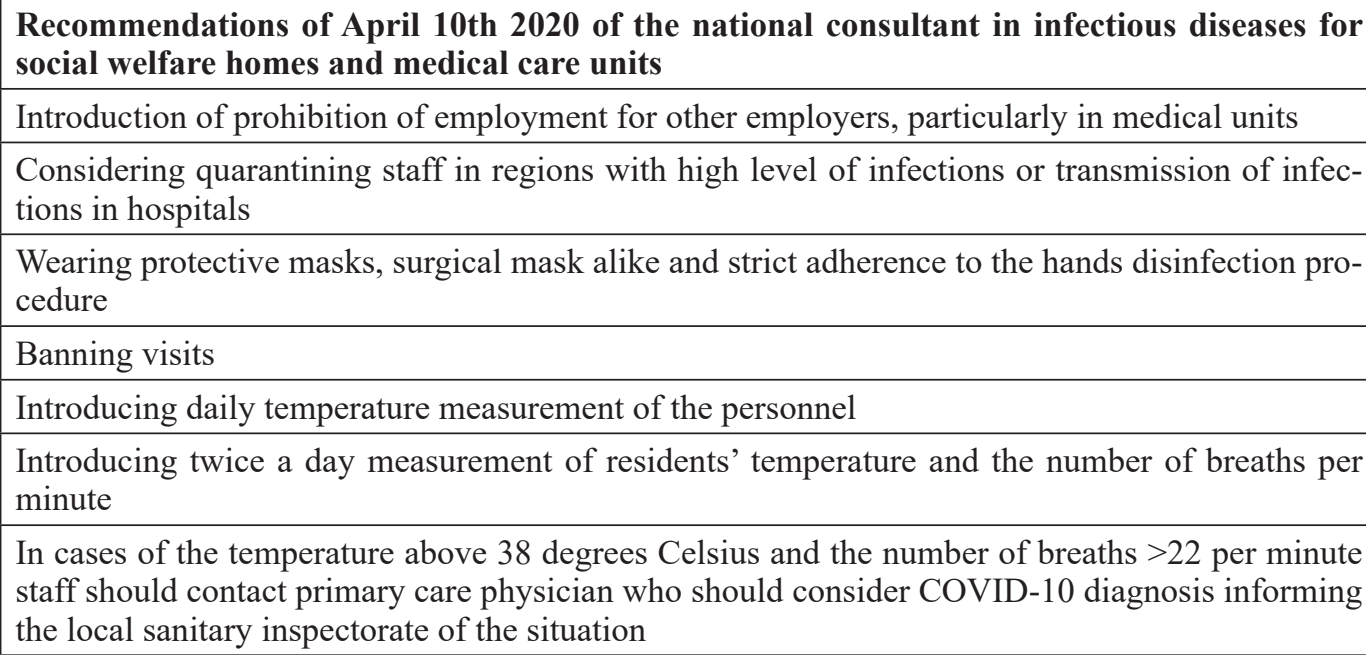

$1 \quad$ http://www.dps.pl/koronawirus/inne/zalecenia-krajowego-konsultanta-w-dziedzinie-chorob-zakaznych-z-dnia-10042020-dla-dps-ow-i-jednostek-opiekunczo-leczniczych-22 
Table 2. Recommendations on organization of nursing and care services in long-term care in relation to the epidemic and the risk of infection with SARS-CoV-1 virus and development of COVID-19 taking into account recommendations of Polish Nursing Society, national consultant in long-term care nursing and national consultant in geriatric nursing ${ }^{l}$

\section{Activities that should be undertaken in stationary and home services in order to decrease the risk of transmission:}

Restriction or prohibition of visits to patients in home care by family, friends and medical staff as well as complete suspension of visit to residents in institutions

Limiting a number of personnel (including medical staff) working directly with patients in nursing and care facilities to a necessary minimum:

- $\quad$ In case of large medical entities separation of sub-teams and sub-sections of nursing and care units

- $\quad$ Due to higher risk of transmission in residential care it is recommended to limit outsourcing and employment of external nursing and care staff, those employed at other medical facilities as long as the system of management and epidemiological safety allows of personnel and patients

Change in the organization of work of medical staff employed in nursing and care units and having parallel employment in other medical units (in particular hospitals) by implementing telework and using ICT systems for consultations of patients in residential care

If a need of personal advice /consultation /examination of nursing and care resident occurs, it should be given with maximum epidemiological protection.

Informing and educating families of patients treated at home care as well as patients themselves on the need of social distancing of chronically ill, including the need for eliminating contacts of home care patients with people who were at potentially risky places are professionally active and may be a source of potential infection due to the nature of their work (public administration, trade workers)

\section{Prevention activities in residential long-term care:}

Management bodies should ensure education of personnel with respect to personal hygiene, hand hygiene and the possibility of transmission of SARS-CoV-2 virus causing COVID-19 (individual training, e-mail training, instructional video, posters) as well as the use of protection clothing (proper putting on, safe removal). Updating the knowledge on hygiene and separation of work and home environment.

Checking regularly messages of the Chief Sanitary Inspector and the Ministry of Health to follow changes in epidemiological situation caused by SARS-CoV-2 virus and follow the rules of qualification of patients for further procedures for in case of contact with persons with suspected infection. Cases that meet criteria of suspected infection should be reported to sanitary inspectorate.

Before working with patients, medical staff providing long-term home care services should perform self-control by measuring body temperature whilst in residential long-term care measurement is performed by a ward nurse, head of the unit or designated nurse on duty. Results of measurement should be noted in medical documentation.

\footnotetext{
$1 \quad$ https://www.gov.pl/web/zdrowie/zalecenia-dotyczace-organizacji-procesu-udzielania-swiadczen-pielegnacyjnych-i-opiekunczych-w-ramach-opieki-dlugoterminowej2
} 
In residential facilities isolation of people with suspected COVID-19 diseases should be assured (with access to toilet, equipped with personal protection, thermometer, tools for hands and environment disinfection), enabling safe stay at the facility under the support from medical doctor or nurse until the arrival of the sanitary transportation team.

Bearing in mind that residents of long-term care facilities, due to the pandemic are deprived of direct support and presence of relatives /informal carers and at the same time they cannot continue contacts via phone of the internet, nursing personnel is obliged to provide them due to their loneliness with the highest standards of care and emotional support.

Personal protective equipment should be used in accordance with epidemiological recommendations for limiting the spread of SARS-CoV-2 virus and COVID-19 disease, taking into account the available personnel, conditions and scope of activities.

Everyone working in long-term care should exercise all precautionary measures and undertake educational and preventive measures to reduce the risk of SARS-CoV-2 virus infection and COVID-19.

Medical briefings, organizational meetings and consultations between team members should take place in the form of telecommunication.

All available, reliable sources about the SARS-CoV-2 virus and COVID-19 disease should be used, e.g. on the website of the Department of Social Medicine and Public Health of the Medical University of Warsaw, in the newsletter tab, there is a weekly presentation on the coronavirus addressed to medical professionals and care.

Care and personnel managers should appoint a coordinator responsible for acquiring and updating knowledge, passing it on to the staff successively and systematically, as well as for increased supervision over the work of staff in the field of implementing the principles of personal protection and protection of charges, and for strengthening their health.

In order to maintain epidemiological safety, it is necessary to resign from group classes of occupational therapy, kinesiotherapy, shared meals in the canteen, etc. Classes should be limited to patient rooms, and rehabilitation to the absolutely indicated basic scope. Rehabilitation treatments and exercises should be carried out individually in the bed and/or the ward.

Due to the fact that the infectivity of the SARS-CoV-2 virus probably begins shortly before the onset of COVID-19 disease symptoms and continues until their resolution and infectious disease in the elderly and pneumonia may begin atypically, in patients who have not yet been diagnosed with severe cognitive impairment, attention should be paid to the symptoms of delirium (such as: behavioural changes, deterioration in verbal-logical contact, inconsistent thinking, lack of concentration, inability to answer questions, confusion, excessive sleepiness, weakness, or previously unobserved agitation) and screened for signs of COVID-19.

Encouraging and enabling residents to stay in remote contact with family and other relatives (telephone, internet - communicator and e-mail), and if necessary - providing assistance in dealing with urgent official matters by e-mail or telephone.

April, were oriented at increasing safety or residents in long-term care institutions and decreasing the risk of transmission of infection, as well as increasing safety of older and chronically ill people in home nursing and care.

Most of these recommendations were adopted as preventive measures by residential care facilities. Among the most 
important ones, potentially with a longterm effect, are limiting employment of nurses and carers to a single facility and introducing shifts of workers. Multiple employment is one the problem of the Polish long-term care and healthcare system. Nurses and carers are low paid, thus often undertaking employment in several facilities in order to make ends meet.

Other preventive measures were related to monitoring health status and caring for residents. Temperature measurement of workers and cared for was introduced. Protection equipment (masks, gloves, disinfection of rooms became obligatory. Further, social welfare homes have changed their way of organizing activities for residents. Rehabilitative services and activities engaging staff from outside the facility were abandoned in order to decrease contacts with outside world and the risk of transmission of infection to the facility. Activities within the facility were organized in regular, small groups. In summertime outside activities on the ground of care units (in gardens) were promoted. Further, social contacts of residents with their families were restricted to telephone calls, on-line chats or visits in prepared spaces, with glass in-between residents and their visitors ${ }^{3}$. Obviously, whilst decreasing the risk of COVID-19 transmission restriction of activities and social contact might negatively impact health status i.e. restricting access to re-

https://www.gov.pl/web/rodzina/dobre-praktyki-domow-pomocy-spolecznej-w-czasie-pandemii habilitation of psychological condition of residents.

Intervention measures adopted by residential care facilities included isolation of residents with symptoms that might be related to COVID-19 and patients with confirmed infection. Residents who enter social welfare home after hospital care should have had also be tested for COVID-19 and isolated for 10 days. In case of the need for transformation of residents to hospitals due to COVID-19, in many cases the army intervenes and helps with evacuation.

The central government, besides consulting and promoting recommendations on preventive procedures in residential care, has undertaken activities to support employees and equip residential care units, though policy response and regulations varied between the two sectors: healthcare and social.

In the healthcare sector regulations in nursing and care units regarding prevention procedures were the same as in other healthcare units and included testing, isolation, single employment of personnel and quarantine of personnel at the risk of infection and transmission of SARS CoV-2 virus due to direct contact with an ill person. The Law on specific solutions related to prevention counteraction and combating COVID-19, other infectious diseases and crisis situations caused by them of March $2^{\text {nd }} 2020$ (Ustawa $z$ dnia 2 marca 2020 r. o szczególnych rozwiazaniach zwiazanych z zapobieganiem, przeciwdziataniem $i$ zwalczaniem COVID-19, innych chorób zakaźnych oraz 
wywolanych nimi sytuacji kryzysowych) introduced remuneration of medical staff on quarantine due to COVID-19 equal to $100 \%$ of salary in healthcare sector, creating inequalities between staff employed in healthcare and social sector while regular rate of remuneration in case of sickness $(80 \%)$ has not been changed. At the same time - facing employment shortages workers in many cases had to perform their duties while on quarantine. These inequalities have been strongly opposed by the trade unions of social workers.

In the social sector additional financial resources were dedicated to temporarily increase remuneration of employees. Still, trade unions were drawing attention to the fact that not all of employed in long-term care received remuneration on-time and to inequalities in working conditions and wages between nursing and care employees in the healthcare and social sector. Financial resources, mostly coming from the European Social Fund, were also used to improve access to preventive equipment (i.e. masks, gloves, coveralls) and adaptation of rooms for the purpose of increase epidemiological safety.

\section{Conclusions}

The unexpected pandemic had a strong impact on the long-term residential care, pointing to underdevelopment of the sector, exposing its imperfections and deficiencies and finally resulting in drawing public attention to the problems of assuring care to older and disabled, incapable of independent living.
The first reaction to the pandemic was quite chaotic, escalated by the lack of coordination between healthcare system and social assistance which resulted in poor access to medical visits and COVID-19 tests both: for the personnel and for the long-term care institutions' residents. It was not only long-term care, but also hospital care faced difficulties with high level of infections during first month of the pandemic. Nursing and care staff shortages, their poor recognition and prestige, as well as low remuneration were among the causes of multiple employment, which in turn contributed to transmission of the virus to institutional care units. This problem was partly solved by adopting wage increase and single employment rule, but only temporarily, whilst long-term solutions are needed as the population of nurses is ageing and the needs for long-term care will only be rising.

The pandemic stimulated discussion on the need for deinstitutionalization in long-term care, which is particularly lobbed for by representatives of the disabled. Deinstitutionalization understood as development of home based services is needed, though given the changes of the society, family changes and low fertility rate, residential care is a solution that is still need and in the months preceding the pandemic the demand for services was much greater than institutional abilities of the public sector entities could meet. The pandemic might decrease this demand on the one hand and impact on the quality of services provided on the other, with higher hygienic standards. 
Finally, home and nursing home services need to be extended to a larger population and provided with highest sanitary standards. In the Autumn, when COVID-19 infections started to rapidly grow, worries have been raised not only about long-term residential care, but care for older or disabled people who might face difficulties high risk of infection or be left without assistance if their family carers get ill. The debate is turning towards establishing not only support to institutions, where infection still occur, but for establishing mechanism to provide assistance to older and dependent people at home, who are also at high risk of negative consequences of the pandemic.

\section{References:}

Comas-Herrera A., Ashcroft E.C., Lorenz-Dant K. (2020), International examples of measures to prevent and manage COVID-19 outbreaks in residential care and nursing home settings, International Long-term Care Policy Network, https:/ltccovid.org/wp-content/ uploads/2020/05/International-measures-to-prevent-and-manage-COVID19-infectionsin-care-homes-11-May-2.pdf [downloaded October 3rd 2020]

Golinowska S., Sowa-Kofta A. (2017), Imbalance between demand and supply of long-term care. The case of post-communist Poland. In: The Routledge Handbook of Social Care Work Around the World, Routledge.

Rządowe Centrum Bezpieczeństwa (2020), Report COVID-19 Sytuacja epidemiologiczna w Polsce i na świecie. Stan na 8 czerwca 2020 godz. 13:30, Warszawa

Szatur-Jaworska B. (2016), Polska polityka społeczna wobec starzenia się ludności w latach 1971-2013, Instytut Polityki Społecznej Uniwersytet Warszawski, Warsaw

Szatur-Jaworska B. (2018), Polityka senioralna - nowa czy stara polityka publiczna w Polsce? in: Polityka społeczna w Polsce. Osiagnięcia $i$ wyzwania, Bednarski M., Wiśniewski Z. (ed), Komitet Nauk o Pracy i Polityce Społecznej PAN, Instytut Pracy i Spraw Socjalnych, Warszawa 